\title{
Baumgarten on Sensible Perfection
}

\author{
J. Colin McQuillan
}

(St. Mary's University)

\section{Introduction}

At the beginning of the 'Preface' to the third (1750) edition of Baumgarten's Metaphysics, we find a response to an unnamed critic of his Reflections on Poetry (1735). Baumgarten reminds us that he had defined the poem as "perfect sensible speech" in his dissertation and says he still thinks this definition is correct. "However," he complains,

one critic wrote that I called a poem 'perfectly sensible' speech, and then twisted the very well-known meaning of perfect, a meaning quite well-known even among schoolboys studying philosophy, into that popular sense in which 'perfectly' can sometimes be substituted for 'entirely' in vague discussions. I had expressly fixed the meaning of 'sensible.' Nevertheless, this gentleman also tediously attaches another meaning to this term, a meaning according to which the Germans of coarse or dull wit sometimes indecently, or even obscenely, speak extremely 'sensible' words in jest. ${ }^{1}$

Although he implores God never to give him time to respond to such critics, Baumgarten's bitterness is evident in his 'Preface.'

That bitterness might explain why he removed the definition of the poem he had proposed in his dissertation from the Metaphysics (1739) ${ }^{2}$.

\footnotetext{
${ }^{1}$ Alexander Baumgarten, Metaphysics, edited and translated by Courtney D. Fugate and John Hymers, London: Bloomsbury, 2013, p. 85. I have modified Fugate's and Hymer's translation of sensitivam orationem perfectam ("perfect sensitive speech") for consistency with Aschenbrenner and Holther's translation of the Reflections on Poetry by replacing "sensitive" with "sensible."

${ }^{2}$ Baumgarten had included his earlier definition of the poem in the first edition of the Metaphysics (1739, §533), but removed it from the second edition (1743) and from subsequent editions. See Metaphysics, $\$ 433$ (n. 24).
}

Philosophica, 44, Lisboa, 2014, pp. 47-64. 
Baumgarten also avoids any reference to perfection in the chapter on the senses he includes in the section on empirical psychology. This is surprising, because the suggestion that indistinct sensible representations could be perfect was one of the most innovative claims Baumgarten had made in the Reflections on Poetry. It represented a profound rejection of the idea associated with Leibniz and Wolff that only the clear and distinct cognition of the understanding and reason could be considered perfect ${ }^{3}$. Perhaps the criticism of his dissertation had scared Baumgarten away from the suggestion that anything sensible might be perfect. Yet the definitions of the poem and aesthetics that he had proposed in his dissertation reappear in his Aesthetics (1750/1758), which was published in the same year as the third edition of the Metaphysics. Why does Baumgarten discuss sensible perfection in the Reflections on Poetry and the Aesthetics, but not the Metaphysics?

In what follows, I will explore Baumgarten's discussions of sense and perfection in the Reflections on Poetry, Metaphysics, and Aesthetics. I will also consider some of the ways in which Georg Friedrich Meier and Immanuel Kant employed Baumgarten's conception of sensible perfection in works on aesthetics and logic. My goal is to discover why Baumgarten thinks sensible perfection is so important in the Reflections on Poetry; why he does not discuss perfection in the sections of the Metaphysics that deal with sense; why the concept of sensible perfection reappears in the Aesthetics; and its influence upon Meier and Kant. In the end, I hope to show that the conception of sensible perfection that Baumgarten introduces in the Reflections on Poetry and Aesthetics is not entirely absent from the Metaphysics, but is downplayed because Baumgarten uses a different conception of perfection elsewhere in Metaphysics, which has to that take precedence over the one he had proposed in the Reflections on Poetry. His reformulation and extension of his original conception of perfection in the Aesthetics set the stage for a new way of thinking about sensibility that would eventually eclipse the Leibnizian-Wolffian philosophy as a whole.

\footnotetext{
${ }^{3}$ For influential studies of Baumgarten's relation to the Leibnizian-Wolffian school, see Ursula Franke, Kunst als Erkenntnis: Die Rolle der Sinnlichkeit in der Ästhetik des Alexander Gottlieb Baumgarten (Studia Leibnitiana Supplementa, Bd. IX), Wiesbaden: Franz Steiner, 1972, pp. 11-14, 37-50. See also Clemens Schwaiger, Alexander Gottlieb Baumgarten: Ein Intellektuelles Porträt, Stuttgart - Bad Cannstatt: Frommann-Holzboog, 2011, pp. 17-26. Unfortunately, none of these studies emphasizes the role the concept of perfection (perfectio, Vollkommenheit) plays in Baumgarten's aesthetics, though Schwaiger provides an instructive account of the role this concept plays in Baumgarten's moral Philosophy. See Schwaiger, Alexander Gottlieb Baumgarten, pp. 155-166.
} 


\section{Sensible Perfection in the Reflections on Poetry}

Baumgarten discusses sensible perfection twice in the Reflections on Poetry. The first is in the discussion of sensible representations that follows his definition of the poem. In order to explain how sensible representations contribute to the "perfect sensible speech" of the poem, Baumgarten distinguishes between obscure, clear, confused, and distinct representations ${ }^{4}$. "In obscure representations," he writes, "there are not contained as many representations of characteristic traits as would suffice for recognizing them and for distinguishing them from others, and as, in fact, are contained in clear representations (by definition). ${ }^{, 5}$ He concludes that a poem whose representations are clear is more perfect than a poem whose representations are obscure; however, he denies that a poem whose representations are distinct is more perfect than a poem whose representations are confused. Baumgarten argues that confused representations are more poetic than distinct representations, because poetry does not strive for conceptual clarity in the same way that philosophy does. Philosophy renders concepts clear and distinct through the "discrimination of characteristics," analyzing concepts and distinguishing their marks until there is nothing left to analyze ${ }^{6}$. Baumgarten does not consider the results of such analysis to be sensible or poetic, so he proposes a different standard for the clarity of sensible representations in poetry ${ }^{7}$. He argues that poetic representations are extensively clear when they gather together a variety of representations and represent more than other confused representations ${ }^{8}$. While extensively clear representations remain confused and lack the intensive clarity of distinct concepts, Baumgarten thinks they contribute to the sensible perfection of the poem, because "more is represented in a sensible way in extensively very clear representations than in those which are less clear"'.

\footnotetext{
${ }^{4}$ Alexander Baumgarten, Reflections on Poetry, edited and translated by Karl Aschenbrenner and William B. Holther, Berkeley: University of California Press, 1954, §9. I have modified Aschenbrenner and Holter's translation of oratio sensitive perfecta ("perfect sensate discourse") for consistency with Fugate and Hymer's translation of the Metaphysics by replacing "discourse" with "speech".

${ }^{5}$ Baumgarten, Reflections on Poetry, $\$ 13$.

${ }^{6}$ Ibid., $\$ 16$.

${ }^{7}$ Ibid., $\$ 14$.

${ }^{8}$ Ibid., $\$ \$ 16-17$.

${ }^{9}$ Ibid., $\$ 17$.
} 
The second discussion of sensible perfection comes at the very end of the Reflections on Poetry. After concluding his survey of the elements of the poem and rival definitions of poetry, Baumgarten declares that philosophical poetics is "the science guiding sensible speech to perfection"10. A science that guides sensible speech to perfection presupposes the existence of sensible representations, so he concludes that philosophical poetics must presuppose another science that he calls "aesthetics" after the Greek word for things perceived by the senses ( $\alpha i \sigma \theta \eta \tau \alpha$ ). Aesthetics is to guide the lower cognitive faculty (sensibility) in the cognition of sensible things in the same way that logic guides the higher cognitive faculty (understanding) toward philosophical knowledge of the truth ${ }^{11}$. While logicians are generally unconcerned with the language they use to communicate their knowledge, Baumgarten insists that aesthetics will have to take a greater interest in the presentation of sensible cognition, because language consists in "articulate sounds" that are perceived by the senses ${ }^{12}$. This leads him to distinguish between two parts of aesthetics. The first part, which he calls "general rhetoric", is concerned with "the unperfected presentation of sensible representations" ". The second part, which deals with "the perfected presentation of sensible representations", is called "general poetics"14. Baumgarten is confident that aesthetics will make a great contribution to philosophy by distinguishing "poetry and ordinary eloquence", but he also seems to worry that distinguishing them will require "no less capable a geometer than did the frontiers of the Phrygians and the Mysians"15.

${ }^{10}$ Ibid., $\$ 115$.

${ }^{11}$ Ibid., $§ \$ 115-116$. The distinction between lower cognitive faculties (sense, imagination, memory, etc.) and higher cognitive faculties (understanding, reason, etc.) was common in the Leibnizian-Wolffian school. See Christian Wolff, Psychologica Empirica, included in Christian Wolff: Gesammelte Werke (II. Abt., Bd. 3), edited by Jean École et al., Hildesheim: Georg Olms Verlag, 2001, §§54-55.

12 Baumgarten, Reflections on Poetry, §117. Baumgarten's claims about the neglect of language in logic are not entirely accurate. Wolff thought language was sufficiently important to devote a chapter to the use of words in his German Logic. See Christian Wolff, Vernünftige Gedanken von den Kräften des menschlichen Verstandes und ihrem richtigen Gebrauche in Erkenntnis der Wahrheit (German Logic), included in Christian Wolff: Gesammelte Werke (I. Abt., Bd. 1), edited by Jean École et al., Hildesheim: Georg Olms Verlag, 2006, Ch. 2.

${ }^{13}$ Baumgarten, Reflections on Poetry, $\$ 117$.

${ }^{14}$ Ibid., $\$ 117$.

${ }^{15}$ Ibid., $\$ 117$. 


\section{Perfection and Sense in the Metaphysics}

Baumgarten has little to say about sensible perfection in his Metaphysics, but he does present a general definition of perfection at the end of the first part of the 'Treatise on the Predicates of Beings' that he includes in his 'Ontology'. According to Baumgarten, perfection is the "agreement" of several things taken together ${ }^{16}$. This agreement must be determined "in conformity to the same ground", so that that there is order in agreement and everything obeys a set of common rules. He goes on to distinguish simple and composite perfection, as well as internal and external perfection, but perhaps the most interesting conception of perfection Baumgarten introduces is "essential" or "transcendental" perfection, which results from the agreement of the essential determinations of a thing ${ }^{17}$. According to Baumgarten, "the essential determinations of each being agree with its essence $(\S 63, \S 40)$ and its attributes $(\S 50, \S 94)$ ", so that "every being is transcendentally perfect" ${ }^{18}$. Later, in the chapter on 'The Real and the Negative', he argues that every being is both "perfect $(\$ 99)$ and real $(\$ 137)$ ", so that the perfection of every being is "the agreement of realities in one reality $(\S 94, \S 140)$ ") He extends this model to the world as a whole in his 'Cosmology,' where he says that the most perfect world "is that in which the greatest of the most parts and the most of the greatest parts what are compossible in a world agree in as great a <unum> being as is possible in a world" 20 .

Unfortunately, Baumgarten does not apply this conception of perfection to the senses in the chapters he devotes to the inferior cognitive faculty in the 'Psychology'. It is curious that he does not say anything substantial about the perfection of the cognition of the inferior cognitive faculty, since he describes its cognition as obscure, confused, and indistinct, and these qualities are the reason why the inferior cognitive faculty is "inferior" when compared to the distinct cognition of the "superior" faculty ${ }^{21}$. It would be helpful if Baumgarten explained

${ }^{16}$ Ibid., $\$ 95$. Baumgarten indicates that he has borrowed this definition of perfection from Christian Wolff and gives reasons why he has not seen fit to change it in the 'Preface' to the second (1743) edition of the Metaphysics. See Baumgarten, Metaphysics, $\S 88$.

${ }^{17}$ Baumgarten, Metaphysics, $\$ 98$.

18 Ibid., \$99.

${ }^{19}$ Ibid., $\$ 141$.

${ }^{20}$ Ibid., $\$ 436$.

${ }^{21}$ Ibid., \$520. He mentions perfection once in the section on the inferior cognitive faculty, when he explains that "a more lively perception is more perfect than a less 
whether and to what extent obscurity, confusion, and indistinctness make the cognition of the inferior cognitive faculty imperfect, but he does not say anything on this subject, even when he argues that "there is something obscure in every sensation, and hence to some extent there is always an admixture of confusion in a sensation, even a distinct one" in the chapter on sense ${ }^{22}$. He even omits any reference to perfection in the definitions he proposes for aesthetics, which becomes "the science of knowing and presenting with regard to the senses", as well as "the logic of the inferior cognitive faculty, the philosophy of the graces and muses, inferior gnoseology, the art of thinking beautifully, the art of the analogue of reason" ${ }^{23}$. Meier reformulates these definitions in his German translation of the Metaphysics (1766), so that aesthetics becomes "the science of the rules of the perfection of sensible knowledge" and "the science of the beautiful" 24 . These definitions are consistent with the ones Meier uses in his Anfangsgründe aller schönen Künste und Wissenschaften (1748-1750) and the ones Baumgarten employs in the Aesthetics. Yet they are nowhere to be found in any of the changes Baumgarten made to the various editions of the Metaphysics ${ }^{25}$.

The only passages in the Metaphysics that are really helpful for understanding Baumgarten's conception of sensible perfection are found in the short section on the faculty of judgment. All judgment, according to Baumgarten, derives from the perception of the perfections and imperfections of things ${ }^{26}$. Since the perception of perfection and imperfection may be more or less distinct, he distinguishes between sensible and intellectual judgment ${ }^{27}$. Sensible judgments are judgments of taste, so Baumgarten makes aesthetic criticism "the art of forming taste, or the art concerning judging sensitively and presenting its judgment" 28 . In a more general sense, criticism is "the science of the rules of distinctly judging perfection or imperfection", though it is unclear whether

lively one $(\$ \S 531,185)$ ", but this is neither terribly informative nor of obvious significance for the perfection of the knowledge of the inferior cognitive faculty. See Baumgarten, Metaphysics, $\$ 532$.

${ }^{22}$ Ibid., $\$ 520,544,624$.

${ }^{23}$ Ibid., $\$ 533$.

${ }^{24}$ Ibid. See also Alexander Baumgarten, Metaphysik, translated by Georg Friedrich Meier, edited by Dagmar Mirbach, Jena: Dietrich Scheglmann Reprints, 2004, $\S 395$.

${ }^{25}$ Baumgarten, Metaphysics, §533.

${ }^{26}$ Ibid., \$606.

${ }^{27}$ Ibid., $\$ 607$.

${ }^{28}$ Ibid., $\$ 607$. 
Baumgarten thinks a distinct critical judgment can be rendered about sensible perceptions that are obscure, confused, and indistinct ${ }^{29}$. His discussion of mature judgment and delicate taste, which are more sensitive to the perfections of things that are partially perfect and partially imperfect, does not help answer this question ${ }^{30}$.

\section{Sensible Perfection in the Aesthetics}

Sensible perfection plays a more significant role and is discussed more frequently in Baumgarten's Aesthetics than in either the Reflections on Poetry or the Metaphysics. Shortly after he defines aesthetics as "the science of sensible cognition", Baumgarten identifies the end of this science as "the perfection of sensible cognition as such" or "beauty" 31 . He responds vigorously to those who think there can be no science of sensible cognition, arguing that it is contrary to reason to neglect any of the perfections of cognition ${ }^{32}$. Yet Baumgarten does not dwell on the paradox that perfect sensible cognition seems to represent. If sensible cognition is "by its very definition... the entirety of all representations that remain below the level of distinctness", then it is difficult to see how it could be perfect. Can obscure, confused, and indistinct cognition be perfect in any meaningful sense?

Baumgarten does not answer the question about the perfection of indistinct sensible cognition directly, but he goes on to describe the universal characteristics of beauty, which suggest that indistinct sensible cognition has many perfections indeed. Among the universal characteristics of beauty, he lists the beauty of things and thoughts, the beauty of order, and the beauty of signification ${ }^{33}$. The beauty of things and thoughts is a perfection of sensible cognition, because things and thoughts are the objects of our cognition. When the objects of sensible cognition are perfect, then the sensible cognition of those objects is also perfect, so it is beautiful. The beauty of order is a perfection of sensible cognition, because there is no perfection without order. When the objects of sensible cognition agree with one another, then sensible cognition is perfectly ordered, so it is beautiful. The beauty of signification is also a perfection of sensible cognition, because we cannot represent the beauty

${ }^{29}$ Ibid.

${ }^{30} \mathrm{Ibid} ., \S 608$.

${ }^{31}$ Alexander Baumgarten, Ästhetik (Teil I), edited and translated into German by Dagmar Mirbach, Hamburg: Meiner Verlag, 2007, §§1, 14.

${ }^{32}$ Baumgarten, Ästhetik, §§5-10.

${ }^{33}$ Ibid., §\$18-20. 
of the objects of sensible cognition and their order without signs. When the signs we use to represent sensible perfection agree with one another, then sensible cognition expresses itself eloquently, and it is beautiful. Baumgarten calls the beauty of things, order, and signification "the three universal graces of cognition", because they are found in "almost all" (omni paene) perfect sensible cognition ${ }^{34}$.

In addition to the universal characteristics of perfect sensible cognition, Baumgarten identifies a number of other perfections that sensible cognition might possess. In the first section alone, he says that richness, greatness, truth, clarity, certainty, and life "comprise the perfection of every cognition, insofar as they are in agreement with each other in representation" ${ }^{35}$. Some of these perfections are the subject of at least one chapter in the metaphysics - richness and greatness are the subject of two chapters each, truth is the subject of another chapter while others are frequently discussed in chapters devoted to other subjects $^{36}$. There can be no doubt that richness, greatness, truth, clarity, certainty, and life are important sensible perfections, even if they do not have the same extension as the beauty of things and thoughts, the beauty of order, and the order of signification.

Two more sensible perfections are worth noting. In the first chapter of the Aesthetics, Baumgarten says "the beauty of sensible cognition and the tastefulness of things that are thought are composite perfections", because "no simple perfection becomes an appearance for us"37. This suggests the perfections of sensible cognition may be simple or complex, but excludes the possibility that simple sensible perfections appear to us. Since appearance is defined as "the unified agreement of thoughts among themselves" in the Aesthetics, every appearance must involve the agreement of several thoughts ${ }^{38}$. The perfection of the sensible cognition depends on the degree to which the different thoughts that constitute the appearance agree with one another. Sensible cognition is less perfect when there is disagreement in appearances, but Baumgarten is willing to

${ }^{34}$ Ibid., $\$ 17,20$.

35 Ibid., $\$ 22$.

${ }^{36}$ See, for example, Baumgarten, Ästhetik, Teil I:IX, XII, XV, XVII, XXVII; Teil II:XXXVII-XXXVIII.

${ }^{37}$ Baumgarten, Ästhetik, §24.

${ }^{38}$ Ibid., §18. Baumgarten treats "appearances" (apparitiones) as a synonym for "sensations" (sensationes) in Baumgarten, Metaphysics, §534, which suggests that he is employing a different conception of appearances in the Aesthetics, where the term "appearance" refers to "the universal agreement of thoughts among themselves". 
admit that there are many exceptions to the rules of beauty, and that some disagreement in appearances does not detract from the overall perfection of sensible cognition ${ }^{39}$. Later in the Aesthetics, Baumgarten will explain that absolute formal perfection is not necessary in metaphysics or aesthetics, because there is also a material perfection in the representation of individual things that should not be dismissed ${ }^{40}$.

\section{Sensible Perfection in Meier and Kant}

Before drawing any conclusions about Baumgarten's conception of sensible perfection, it is worthwhile to consider the use Meier and Kant make of this concept. We have already seen that Meier makes aesthetics the science of perfect sensible cognition in his translation of Baumgarten's Metaphysics; however, he also uses the concept of sensible perfection extensively in his Anfangsgründe aller schönen Künste und Wissenschaften (1748-50) and in his Vernunftlehre (1752). Kant rarely mentions the concept of sensible perfection in his published works, but he discusses it frequently in his lectures on logic, which were based on Meier's Vernunftlehre. The different ways in which Meier and Kant use this concept highlights a tension in Baumgarten's thought and sets the stage for Kant's more radical break with the Leibnizian-Wolffian philosophy.

One of the first things that becomes apparent in Meier's work is that he uses the concept of perfection much more promiscuously than Baumgarten does. On the first page of the 'Introduction' to the Anfangsgründe, Meier talks about the perfection of appearance, the perfection of beautiful cognition, and the perfection of the intellectual world $^{41}$. He goes on to discuss the perfection of aesthetic cognition, which he says is "perfectly analogous" to the perfection of logical cognition, even though aesthetics is concerned with the sensible cognition of the lower cognitive faculty rather than the philosophical cognition of the higher cognitive faculty ${ }^{42}$. This analogy guarantees the possibility of the science of sensible cognition Baumgarten had proposed. According to Meier, this science concerns itself with "the rules of perfections and beauties in general" as well as "the doctrine of the soul, especially

\footnotetext{
39 Baumgarten, Ästhetik, §\$24-25.

${ }^{40}$ Ibid., $\$ 559-565$.

${ }^{41}$ Georg Friedrich Meier, Anfangsgründe aller schönen Wissenschaften (2. Auf, 1. Teil), Magdeburg: Hemmerde, 1754, §1.

${ }^{42}$ Meier, Anfangsgründe aller schönen Wissenschaften, §§2-3.
} 
concerning the nature of the lower sensible cognitive faculty"43. Each of these tasks is reflected in the structure of the Anfangsgründe. Many of the chapters of the first volume are devoted to specific aesthetic perfections, while the second volume addresses the specific faculties that belong to the lower cognitive faculty. It should also be noted that the aesthetic perfections that Meier discusses in the first volume of the Anfangsgründe - richness, greatness, probability, vivacity, certainty, and sensible life are very similar to the ones Baumgarten identifies in the Aesthetics ${ }^{44}$. This should not be surprising, as Meier acknowledges his debt to Baumgarten in his 'Preface' and also in the 'Introduction' to the Anfangsgründe ${ }^{45}$.

Meier's preoccupation with perfection is also evident in the Vernunftlehre, where he discusses the perfection of cognition in general and the difference between the logical and aesthetic perfections of cognition. According to Meier, cognition is perfect when a variety of things agree in a certain respect in our cognition ${ }^{46}$. Cognition is logically perfect when that agreement is distinct and aesthetically perfect when it is beautiful but indistinct ${ }^{47}$. The Vernunftlehre is an investigation of learned cognition, which is a kind of logically perfect cognition, so Meier does not have a great deal to say about aesthetically perfect cognition; yet he is eager to show that logically perfect cognition can be combined with aesthetically perfect cognition to produce a kind of cognition that is both learned and beautiful ${ }^{48}$. After listing all of the other logical perfections of cognition - extension, magnitude, truth, distinctness, certainty, and practicality - he argues that learned cognition that possesses all of the logical perfections is still not as perfect as cognition that is both learned and beautiful ${ }^{49}$. This is a strange thing to say, since the logical

${ }^{43}$ Ibid., $\S \S 3-5$.

44 Although Baumgarten's and Meier's lists of sensible perfections are similar, they are not identical. Baumgarten includes "clarity" (claritas) in his list, but Meier does not. Meier also distinguishes between "vivacity" (Lebhaftigkeit) and "sensible life" (sinnlichen Leben) in a way that Baumgarten does not. Finally, Meier replaces Baumgarten's "truth" (veritas) with "probability" (Wahrscheinlichkeit).

${ }^{45}$ Meier, Anfangsgründe aller schönen wissenschaften, ii, §6.

${ }^{46}$ Georg Friedrich Meier, Auszug aus der Vernunftlehre (Kant's Gesammelte Schriften, Bd. XVI), edited by Erich Adickes, Berlin: Walter de Gruyter, 1924, $\S 22$.

${ }^{47}$ Meier, Auszug aus der Vernunftlehre, $\$ 19,21$.

48 Ibid., $\$ 24$.

${ }^{49}$ Ibid., $24-\S 30$. 
distinctness of learned cognition would seem to exclude the aesthetic indistinctness of beautiful cognition.

Kant seems to have recognized this difficulty in Meier's account of logical and aesthetic perfection. After dutifully rehearsing Meier's account of the perfections of cognition in his logic lectures, Kant expresses some doubts about the idea that any cognition could be both logically and aesthetically perfect. Commenting on Meier's claim that "we ought to make our cognition at once logically and aesthetically perfect", Kant asks "But who can achieve this?" "In each part of our cognition", he continues,

such a thing can very often fail to occur. If I want, e.g., to make a book logically perfect, then I do not have to produce everywhere at the same time the aesthetic and practical, nor can I. And if, on the other hand, I want to make a book aesthetically or practically perfect, then I cannot always, in doing so, think about the production of the logically perfect. ${ }^{50}$

He takes a similar view of the combination of aesthetic and logical clarity in the 'Preface' to the first (A) edition of the Critique of Pure Reason, where he says he excluded examples and illustrations from the text, not only because they would make the work too long, but also because he feared aesthetic considerations would "paint over and make unrecognizable" the logical structure of his argument with their "bright colors" 51 . While he does not claim logical and aesthetic perfection are mutually exclusive as a matter of principle, Kant is much less optimistic than Meier about the possibility of combining them.

Kant also came to doubt the idea that distinctness and indistinctness are sufficient to distinguish between sensible and intellectual cognition ${ }^{52}$. Although he attributes this idea to Leibniz and Wolff, Baumgarten and Meier are equally subject to the objections Kant raises against this "merely logical" distinction in his inaugural dissertation, in the first Critique, in the Prolegomena, and in later works like On a Discovery and

${ }^{50}$ Immanuel Kant, Lectures on Logic (The Blomberg Logic. 1770s), edited and translated by J. Michael Young, Cambridge: Cambridge University Press, 1992, p. 43 (XXIV: 59).

${ }^{51}$ See, for example, Immanuel Kant, Critique of Pure Reason, edited and translated by Paul Guyer and Allen W. Wood, Cambridge: Cambridge University Press, 1998, Axvii-Axviii.

${ }^{52}$ See, for example, Immanuel Kant, Lectures on Metaphysics (Metaphysik $L_{1}, c$. 1770s), edited and translated by Karl Ameriks and Steve Naragon, Cambridge: Cambridge University Press, 1997, p. 58 (XXVIII: 240). 
the drafts for his essay on the progress of metaphysics ${ }^{53}$. Instead of using distinctness to separate what is sensible and what is intellectual in our cognition, Kant distinguishes them by their origin and content ${ }^{54}$. Sensible cognition is sensible because it has its origin in the faculty of sensibility, while intellectual cognition is intellectual because it derives from the understanding. The faculty of sensibility provides us with intuitions, while concepts are functions of the understanding. Intuitions and concepts may be more or less distinct, but intuitions are not sensible because they are indistinct, nor are concepts intellectual because they are distinct. The defenders of Leibniz and Wolff, like Mendelssohn and Eberhard, thought Kant was too quick to dismiss the role distinctness plays in distinguishing the sensible and the intellectual, but the subsequent history of German philosophy shows that their objections fell on deaf ears ${ }^{55}$.

\section{Conclusions}

Having surveyed Baumgarten's discussions of sensible perfection in the Reflections on Poetry, Metaphysics, and Aesthetics, and taken stock of Meier's and Kant's use of this concept, we are now in a position to draw some conclusions. The first concerns the conception of sensible perfection Baumgarten employs in the Reflections on Poetry; the second concerns the conception of perfection he uses in the Metaphysics and its absence from the chapter on the senses; the third concerns the return of Baumgarten's conception of sensible perfection in the Aesthetics; and the fourth concerns the reception of Baumgarten's conception of sensible

53 Immanuel Kant, Theoretical Philosophy Before 1770 (Inaugural Dissertation, 1770), edited and translated by David Walford and Ralf Meerbote, Cambridge: Cambridge University Press, 1992, p. 387 (II: 394-395). See also Kant, Critique of Pure Reason, A44/B62. See also Immanuel Kant, Theoretical Philosophy After 1781 (Prolegomena, 1783; On a Discovery, 1790; What Real Progress, c. 1793), edited and translated by Henry Allison and Peter Heath, Cambridge: Cambridge University Press, 2002, pp. 85, 310, 368 (IV: 290, VIII: 219-220, XX: 277).

${ }^{54}$ See, for example, Kant, Critique of Pure Reason, A50/B74-A52/B76.

55 Moses Mendelssohn, Morning Hours: Lectures on God's Existence, translated by Daniel O. Dahlstrom and Corey Dyck, Dodrecht: Springer, 2011, pp. 101-103. See also Johann August Eberhard, "Über den wesentlich Unterschied der Erkenntnis durch die Sinne und durch den Verstand," included in Immanuel Kant: Der Streit mit Johann August Eberhard, edited by Marion Lauschke and Manfred Zahn, Hamburg: Meiner, 1998, pp.60-69. See also Frederick Beiser, The Fate of Reason: German Philosophy from Kant to Fichte, Cambridge: Harvard University Press, 1987, pp. 193-225. 
perfection, whose influence can be found in Kant's conception of sensibility, despite his objections to Leibniz, Wolff, Baumgarten, and Meier.

The conception of sensible perfection that Baumgarten employs in the Reflections on Poetry is based on Leibniz's and Wolff's claim that a concept is adequate (adequate, vollständig) when we have clear and distinct knowledge of all of the marks that constitute that concept ${ }^{56}$. Christian Wolff uses this conception of cognitive perfection to distinguish the lower cognitive faculty (sense) from the higher cognitive faculty (understanding) in his empirical psychology. The former is concerned with obscure and confused concepts, while the latter is concerned with distinct notions ${ }^{57}$. Wolff's distinction suggests that only intellectual cognition can be perfect, but Baumgarten introduces a different standard of perfection for sensible cognition in the Reflections on Poetry. He argues that sensible cognition, sensible representations, and the sensible speech of rhetoric and poetry can be considered perfect, so long as they are clear. An orthodox Wolffian would have rejected this claim as absurd, because it implies that confused and indistinct cognition can still be perfect; yet Baumgarten remains committed to view that perfect sensible representations are clear and confused but not distinct. He also devises a new way of clarifying sensible representations that avoids the analytical method Wolff had proposed. Instead of proceeding like a philosopher and distinguishing the marks that constitute a concept, Baumgarten suggests that sensible representations can be clarified by increasing the number of marks a representation contains ${ }^{58}$. As an example, he cites Homer's reference to "leaders and chieftans, commanders of ships, and all the fleet" in the second book Iliad" ${ }^{59}$. While some readers might think everything after "leaders" is redundant, Baumgarten thinks the passage is improved by mentioning "chieftans" and "commanders", because the point Homer wishes to emphasize becomes clearer. This shows that the perfection of sensible representations derives from their extensive clarity, rather than the intensive clarity that leads to distinct philosophical cognition.

${ }^{56}$ Gottfried Wilhelm Leibniz, Meditations on Knowledge, Truth, and Ideas, included in G. W. Leibniz: Philosophical Essays, translated by Roger Ariew and Daniel Garber, Indianapolis: Hackett, 1989, p. 24. See also Wolff, German Logic, Ch. 1, $\S 16$.

57 Wolff, Psychologica Empirica, §§54-55.

${ }^{58}$ Baumgarten, Reflections on Poetry, §§16-19. See also Baumgarten, Metaphysics, $\S 531$.

${ }^{59}$ Baumgarten, Reflections on Poetry, §19. 
Baumgarten does not emphasize his revision of the Wolffian conception of cognitive perfection in the Metaphysics, because he employs a different conception of perfection in the sections on ontology and cosmology. This conception of perfection is defined by agreement rather than distinctness or beauty. Perfection as agreement takes precedence over perfection as distinctness or beauty, because ontology and cosmology are more fundamental parts of metaphysics than empirical psychology. Ontology is concerned with "the more general predicates of a being", while cosmology is "the science of the general predicates of the world" ${ }^{60}$. Empirical psychology deals with the mind and the perfections of its cognition, but the mind has to exist and be a part of the world before it can have distinct or beautiful cognition. In order for the mind to exist and be a part of the world, its different elements have to agree with one another in their essence ${ }^{61}$. That is why perfection as agreement takes precedence over perfection as distinctness or beauty; yet the former does not exclude the latter as a matter of principle. Although Baumgarten does not use the language of sensible perfection very often in his discussion of empirical psychology, he connects sensible cognition to a kind of perfection when he says a lively sensible perception is more perfect than a less lively one. Later, in the discussion of taste in the section on the faculty of judgment, he connects the conception of perfection as agreement to the conception of sensible perfection more explicitly ${ }^{62}$. These examples indicate that Baumgarten still thinks that sensible perfection is possible, but there are also less explicit appeals to sensible perfection in the Metaphysics. Baumgarten uses the same distinctions between obscure, clear, confused, and distinct cognition, as well as the distinction between intensive and extensive clarity, that he had employed in his discussion of the perfection of sensible representations in the Reflections on Poetry, which suggests that he did not abandon the concept of sensible perfection in the Metaphysics. He simply avoided referring to a conception of cognitive perfection that might conflict with the ontological and cosmological conception of perfection he employs elsewhere in the book.

Baumgarten does not need to avoid the ontological and cosmological conception of perfection in the Aesthetics, so he returns to the standards of cognitive perfection he had introduced in the Reflections on Poetry. He identifies aesthetics as the science that will guide the indistinct cognition of the lower cognitive faculty to perfection, just as he did in the

\footnotetext{
${ }^{60}$ Baumgarten, Metaphysics, $\S 4,351$.

${ }^{61}$ Ibid., $\$ 98-99$.

${ }^{62}$ Ibid., $\$$ 607-608.
} 
Reflections on Poetry, but he does not limit his discussion of sensible perfection to extensive clarity ${ }^{63}$. Instead, Baumgarten introduces a number of additional perfections of sensible cognition and develops them at considerable length. His discussions of the beauty of things and thoughts, the beauty of order, and the beauty of signification show perfect sensible cognition is concerned with the beauty of external objects and the way they are represented in the mind; that ugly things may be represented in beautiful ways in perfect sensible cognition; that perfect sensible cognition respects the order of appearances and their agreement with one another; and that perfect sensible cognition represents itself eloquently in speech and writing ${ }^{64}$. His treatment of the richness, greatness, truth, certainty, and life of sensibly perfect cognition throughout the Aesthetics also suggests that the perfections of sensible cognition extend far beyond clarity. However, the most important way Baumgarten develops his conception of sensible perfection in the Aesthetics is his identification of perfect sensible cognition and beauty, which is entirely absent from the Reflections on Poetry. A closely related definition can be found in the Metaphysics, where Baumgarten calls beauty "the perfection observable by taste in the broader sense", but this could leave readers with the impression that aesthetics is a part of cosmology that describes the pleasing qualities of things ${ }^{65}$. By making beauty the perfection of sensible cognition in the Aesthetics, Baumgarten completes his revision of the standards of cognitive perfection that Leibniz and Wolff had introduced, setting the stage for a very different way of thinking about sensibility.

Meier made the most of Baumgarten's conception of sensible perfection in his Anfangsgründe and Vernunftlehre, promoting his new science of aesthetics and urging his readers to combine the perfections of sensible and intellectual cognition. Yet one could argue that Kant is actually the most influential figure in the reception of Baumgarten's conception of sensible perfection. Even though he rejected the idea that sensible cognition is confused and indistinct and reduced the role that cognitive perfection played in aesthetics and logic, Kant accepted one of the most radical implications of Baumgarten's conception of sensible perfection and pursued its consequences more persistently than either

\footnotetext{
${ }^{63}$ Baumgarten, Ästhetik, §17.

${ }^{64}$ Ibid., $\$ 18-20$.

${ }^{65}$ Ibid., §14. See also Baumgarten, Metaphysics, §662. Dagmar Mirbach provides a helpful commentary on the relationship between beauty as "perfectio phaenomenon" and beauty as "perfectio cognitionis sensitivae" in her introduction to the Aesthetics. See Baumgarten, Ästhetik, LIII-LIX.
} 
Baumgarten or Meier. If Baumgarten's conception of sensible perfection is intended to distinguish sensible and intellectual cognition, then Kant is the philosopher who faced that challenge most squarely. By focusing on the differences in the origin and content of sensible intuition and pure concepts of the understanding, Kant was able to separate the two sources of our cognition more decisively than any of his predecessors ${ }^{66}$. The differences between Kant's account of the difference between sensibility and the understanding and the account of the difference between the lower and higher cognitive faculties that Baumgarten inherited from Wolff should not lead us to discount Baumgarten's influence on Kant or the way his account of sensible perfection set the stage for his more radical distinction between intuitions and concepts. Baumgarten's conception of sensible perfection anticipates Kant's account of the difference between sensibility and the understanding in the Critique of Pure Reason, because it began the process of separating sensibility from the intellectualizing tendencies of Leibniz and Wolff.

\section{Bibliography}

BAUMGARTEN, Alexander, Metaphysics, edited and translated by Courtney D. Fugate and John Hymers, London: Bloomsbury, 2003.

BAUMGARTEN, Alexander, Ästhetik, edited and translated into German by Dagmar Mirbach, Hamburg: Meiner Verlag, 2007.

BAUMGARTEN, Alexander, Metaphysik, translated by Georg Friedrich Meier, edited by Dagmar Mirbach, Jena: Dietrich Scheglmann Reprints, 2004.

BAUMGARTEN, Alexander, Reflections on Poetry, edited and translated by Karl Aschenbrenner and William B. Holther, Berkeley: University of California Press, 1954.

BEISER, Frederick, The Fate of Reason: German Philosophy from Kant to Fichte, Cambridge: Harvard University Press, 1987.

EBERHARD, Johann August, "Über den wesentlich Unterschied der Erkenntnis durch die Sinne und durch den Verstand," included in Immanuel Kant: Der Streit mit Johann August Eberhard, edited by Marion Lauschke and Manfred Zahn, Hamburg: Meiner, 1998.

FRANKE, Ursula, Kunst als Erkenntnis: Die Rolle der Sinnlichkeit in der Ästhetik des Alexander Gottlieb Baumgarten (Studia Leibnitiana Supplementa, Bd. IX), Wiesbaden: Franz Steiner, 1972.

KANT, Immanuel, Theoretical Philosophy After 1781, edited and translated by Henry Allison and Peter Heath, Cambridge: Cambridge University Press, 2002.

${ }^{66}$ See Colin McQuillan, "The History of a Distinction: Sensible and Intellectual Cognition from Baumgarten to Kant," included in Rethinking Kant, vol. III, edited by Oliver Thorndike, Cambridge: Cambridge Scholars Press, 2011, pp. 180-199. 
KANT, Immanuel, Critique of Pure Reason, edited and translated by Paul Guyer and Allen W. Wood, Cambridge: Cambridge University Press, 1998.

KANT, Immanuel, Lectures on Metaphysics, edited and translated by Karl Ameriks and Steve Naragon, Cambridge: Cambridge University Press, 1997.

KANT, Immanuel, Theoretical Philosophy Before 1770, edited and translated by David Walford and Ralf Meerbote, Cambridge: Cambridge University Press, 1992.

KANT, Immanuel, Lectures on Logic, edited and translated by J. Michael Young, Cambridge: Cambridge University Press, 1992.

LEIBNIZ, Gottfried Wilhelm, Meditations on Knowledge, Truth, and Ideas, Included in G.W. Leibniz: Philosophical Essays, translated by Roger Ariew and Daniel Garber, Indianapolis: Hackett, 1989.

MCQUILLAN, Colin, "The History of a Distinction: Sensible and Intellectual Cognition from Baumgarten to Kant", included in Rethinking Kant: Volume III, edited by Oliver Thorndike, Cambridge: Cambridge Scholars Press, 2011.

MEIER, Georg Friedrich, Auszug aus der Vernunftlehre (Kant's Gesammelte Schriften, Bd. XVI), edited by Erich Adickes, Berlin: Walter de Gruyter, 1924.

MEIER, Georg Friedrich, Anfangsgründe aller schönen Wissenschaften (2. Auf.), Magdeburg: Hemmerde, 1754.

MENDELSSOHN, Moses, Morning Hours: Lectures on God's Existence, translated by Daniel O. Dahlstrom and Corey Dyck, Dodrecht: Springer, 2011.

SCHWAIGER, Clemens, Alexander Gottlieb Baumgarten: Ein Intellektuelles Porträt, Stuttgart - Bad Cannstatt: Frommann-Holzboog, 2011.

WOLFF, Christian, Vernünftige Gedanken von den Kräften des menschlichen Verstandes und ihrem richtigen Gebrauche in Erkenntnis der Warheit (German Logic), included in Christian Wolff: Gesammelte Werke (I. Abt., Bd. 1), edited by Jean École et al., Hildesheim: Georg Olms Verlag, 2006.

WOLFF, Christian, Psychologica Empirica, included in Christian Wolff: Gesammelte Werke (II. Abt., Bd. 3), edited by Jean École et al., Hildesheim: Georg Olms Verlag, 2001.

\section{ABSTRACT}

One of the most important concepts Baumgarten introduces in his Reflections on Poetry is the concept of sensible perfection. It is surprising that Baumgarten does not elaborate upon this concept in his Metaphysics, since it plays such an important role in the new science of aesthetics that he proposes at the end of the Reflections on Poetry and then further develops in the Aesthetics. This article considers the significance of the absence of sensible perfection from the Metaphysics and its implications for Baumgarten's aesthetics, before turning to the use Meier and Kant make of Baumgarten's concept. In the end, this article shows that Baumgarten did not abandon his conception of sensible perfection in 
the Metaphysics, though its influence declined significantly after Kant rejected the idea that sensibility and the understanding could be distinguished by the perfections of their cognition.

Keywords: Baumgarten, Kant, aesthetics, sensibility, perfection

\section{RESUMO}

Um dos mais importantes conceitos que Baumgarten introduz nas suas Reflexões sobre Poesia é o conceito de perfeição sensível. É surpreendente que Baumgarten não elabore acerca deste conceito na sua Metafísica, visto possuir um papel tão importante na nova ciência estética que ele propõe no final das Reflexões sobre Poesia e que aprofunda na Estética. Este artigo aborda o significado da ausência da perfeição sensível na Metafísica e as suas implicações para a estética de Baumgarten, antes de analisar o uso que Meier e Kant fazem do conceito de Baumgarten. No final, este artigo mostra que Baumgarten não abandonou a sua concepção de perfeição sensível na Metafísica, apesar de a sua influência ter diminuído significativamente após Kant ter rejeitado a ideia de que a sensibilidade e o entendimento poderiam distinguir-se pelas perfeições da respectiva cognição.

Palavras-chave: Baumgarten, Kant, estética, sensibilidade, perfeição 